\title{
PREVALENCE OF LOW BACK PAIN AND EVALUATION OF RISK FACTORS IN HOSPITALIZED PATIENTS
}

\author{
PREVALÊNCIA DE LOMBALGIA E AVALIAÇÃO DE FATORES DE RISCO EM PACIENTES \\ HOSPITALIZADOS
}

\section{PREVALENCIA DE LUMBALGIA Y EVALUACIÓN DE FACTORES DE RIESGO EN PACIENTES HOSPITALIZADOS}

\author{
João Pedro de Salles Netto ${ }^{1}$, Fernanda Andrea Minutti Navarro ${ }^{1}$, Rodrigo Yuiti NakaO ${ }^{1}$, Maxwel de Menezes Santos ${ }^{2}$. Luiz Cláudio Lacerda Rodrigues \\ 1. Hospital Santa Marcelina, Spine Service, São Paulo, SP, Brazil. \\ 2. Faculdade de Medicina Santa Marcelina, São Paulo, SP, Brazil.
}

\begin{abstract}
Objective: To determine the prevalence of low back pain and to establish a correlation with risk factors for the development of low back pain in a teaching hospital in the East Zone of São Paulo. Method: This is a cross-sectional, observational, analytical study, in which 90 patients from the teaching hospital wards were evaluated. Internationally validated instruments were used to assess clinical, epidemiological and behavioral aspects. Results: The prevalence rate obtained was $57.73 \%$, which is considered high compared to the rates in studies conducted outside of the hospital environment. There was predominance in the female sex, at 30.13\% (SSD 5.32\%). Sleep disturbances, measured indirectly through hours of sleep and the average pain score $(p=0.007)$, seem to act as a risk factor. The instruments for checking pain seem to be more effective when used together, with an association being observed between the Oswestry questionnaire $(\mathrm{ODI})$ and the visual analog scale (VAS) for pain $(\mathrm{p}=0.000)$. Conclusions: There is a prevalence of low back pain among institutionalized individuals, especially those who are hospitalized, compared to rates observed outside the hospital environment. Level of evidence IV; Cross-sectional observational.
\end{abstract}

Keywords: Low Back Pain; Spine; Prevalence; Risk Factors.

\section{RESUMO}

Objetivo: Determinar a prevalência de lombalgia e estabelecer correlação com fatores de risco para o desenvolvimento de dor lombar em um Hospital Escola da Zona Leste de São Paulo. Métodos: Trata-se de um estudo analítico observacional transversal, no qual foram avaliados 90 pacientes provenientes das enfermarias do Hospital Escola. Foram empregados instrumentos internacionalmente validados para avaliar aspectos clínicos, epidemiológicos e comportamentais. Resultados: A taxa de prevalência obtida foi de 57,73\%, considerada alta em comparação com as taxas das pesquisadas realizadas fora do ambiente hospitalar. Houve predomínio do sexo feminino, com 30,13\% (DPa 5,32\%). Os distúrbios do sono, medidos indiretamente por meio de horas de sono e a média da graduação de dor ( $p=0,007$ ), parecem agir como fator de risco. Os instrumentos para verificação da dor parecem ter maior eficácia quando usados em conjunto, sendo observada uma associação entre o questionário de Oswestry (ODI) e a escala visual analógica (EVA) de dor ( $P=0,000)$. Conclusões: Constatou-se maior taxa da prevalência de lombalgia entre os indivíduos institucionalizados, principalmente, os hospitalizados, comparada a taxas observadas fora do contexto hospitalar. Nível de evidência IV; Estudo Observacional Transversal.

Descritores: Dor Lombar; Coluna Vertebral; Prevalência; Fatores de Risco.

\section{RESUMEN}

Objetivo: Determinar la prevalencia de lumbalgia y establecer una correlación con los factores de riesgo para el desarrollo del dolor lumbar en un hospital universitario en la Zona Este de São Paulo. Métodos: Este es un estudio analítico observacional de corte transversal, en el que se evaluaron 90 pacientes de las enfermerías del hospital universitario. Se utilizaron instrumentos validados internacionalmente para evaluar aspectos clínicos, epidemiológicos y de comportamiento. Resultados: La tasa de prevalencia obtenida fue de 57,73\%, considerada alta en comparación con las tasas de los encuestados fuera del ámbito hospitalario. Predominó el sexo femenino, con un 30,13\%

(SSD 5,32\%). Los trastornos del sueño, medidos indirectamente a través de horas de sueño y la puntuación promedio de dolor $(p=0,007)$, parecen actuar como un factor de riesgo. Los instrumentos para controlar el dolor parecen ser más efectivos cuando se usan juntos, con una asociación entre el cuestionario de Oswestry (ODI) y la escala visual analógica (EVA) del dolor ( $p=0,000)$. Conclusiones: Se encontró una mayor tasa de prevalencia de dolor lumbar entre los individuos institucionalizados, especialmente los hospitalizados, en comparación con las tasas observadas fuera del contexto hospitalario. Nivel de Evidencia IV; Estudio Observacional Transversal.

Descriptores: Dolor de la Región Llumbar; Columna Vertebral; Prevalencia; Factores de Riesgo. 


\section{INTRODUCTION}

Low back pain is a component of a range of musculoskeletal disorders seen as important health problems that can significantly affect the quality of life. Studies suggest that around $84 \%$ of the general population will report this type of pain at some point in their lives with a point prevalence of $11.9 \%$ of the world population. ${ }^{1,2}$ Frequent in both sexes, especially in the 30 to 50 years of age range, low back pain is associated with relevant healthcare expenses, being one of the main causes of medical care in the world, second only to headaches. ${ }^{1}$ However, these numbers may be underestimated since less than $60 \%$ of people with low back pain seek treatment. ${ }^{2}$

In a study of the working population enrolled in the Professional Rehabilitation Program of the National Social Security Institute (INSS) in the city of São Luís/ MA, the prevalence of low back pain was 33.3\%. The sample was composed mostly of married workers, with a low level of education, male, of a productive age and on leave from work for more than a year, associated with performing professional activities that required static posture, repetitive movement and lifting weight. ${ }^{3}$

Spine problems are often divided into acute and chronic, with the main differentiating factor being the period of the pain; considered acute if lasting up to 30 days and chronic if it persists longer. ${ }^{4}$ According to the National Health Survey conducted in 2103, chronic low back problems are more common. Approximately 27 million people 18 years of age and older reported chronic back problems in Brazil. There was a higher proportion of women (21.1\%) than men (15.5\%) and, as the age increased, so did the estimated proportion of the indicator. This proportion was significantly higher among people who had not completed primary school $(24.6 \%)$ than in the other educational level categories. ${ }^{5}$

Another earlier study that reported a prevalence of chronic low back pain of $4.2 \%$ in the population, showed that variables of sex, age, marital status, educational level, tobacco use, body mass index, work lying down, carrying weight and performing repetitive movements were associated with chronic low back pain. ${ }^{6}$

Low back pain is classified by inflammatory or mechanical characteristics, opening up a range of possibilities for a better investigation of the origin of pain. The patient should be asked about the following warning signs, such as signs of tumor or infection, signs of fracture and cauda equina syndrome, which may stem from systemic diseases. ${ }^{7}$

The diagnosis requires a careful anamnesis and a good physical examination. Then, the mechanisms of the physical examination findings are evaluated, mainly those related to changes in physiological movements (flexion and extension), those resulting from compression of the lumbosacral plexus nerve roots, the non-organic signs in psychosomatic low back pain and the warning signs in low back pain of atypical evolution (with more than four weeks in duration) accompanied by systemic complaints resulting from tumors, infections and/or fractures. ${ }^{8}$

When warning signs are present, the use of complementary examinations is indicated for the diagnosis of secondary causes. Such an indication is not present when a degenerative mechanism is the suspected cause of the low back pain, given that the patient history, the physical examination and the absence of warning signs are sufficient for diagnosis and proper management. Thus, to better characterize the lesions, new techniques, such as magnetic resonance with axial load, which seems more effective and sensitive than the traditional method, especially in obese patients, are being studied. ${ }^{8}$

Risk factors for the development of low back pain may be linked to psychosocial, behavioral and occupational aspects, such as high demand for tasks, dissatisfaction of the work environment, as well as a lower socioeconomic level, obesity, tobacco use, sedentarism and sleep quality. Thus, recent research indicates that exposure to a greater number of modifiable physical and psychosocial factors increases the risk of an episode of low back pain. ${ }^{9}$

International instruments exist that can help to characterize low back pain, mainly by measuring the impact that it has on the quality of life. Among them, the Oswestry disability index (ODI) questionnaire, the Roland-Morris (RM) disability assessment and the SF-36 quality of life questionnaire. ${ }^{10-12}$

Based on this context, the objective of this study was to determine the prevalence of low back pain, in a hospital in the East Zone of São Paulo, in order to create a statistical database on the proposed topic. In addition, the secondary objectives are to determine the epidemiological profile of the referenced population, to identify the degree of effectiveness of the tertiary prevention care provided to the patient, to evaluate the impact of low back pain, to verify the risk factors that most contribute to the prevalence of low back pain and to assess factors that contribute to orthostatic posture of the patients while they are hospitalized.

\section{METHODS}

Patients of both sexes, over 18 years of age, literate, with no restriction by race, referred from different primary or secondary care services with varied complaints for specialized care at the Hospital Santa Marcelina de Itaquera - East Zone of São Paulo. The study was approved by the Institutional Review Board as opinion 2.948.224 and participation was contingent on agreement by the patient or their legal representative to participate by signing the Informed Consent Form (ICF)

There was no form of medical treatment during the interviews, which were intended only for study data collection. The patients had to be able to communicate with the interviewers and those with speech impairments needed to be accompanied by their legal representatives.

Patients under 18 years of age, pregnant patients, patients who had undergone spine surgery and patients who did not have the cognitive skills to answer the questionnaires were excluded.

The research was conducted at the Hospital Santa Marcelina, located in Itaquera, in the East Zone of the city of São Paulo. The interviews were held in the ward on Saturdays during between-meal hours and in the absence of procedures provided by the assisting team, during the period from December 2018 to February 2019.

A cross-sectional, observational, analytical study was conducted over 12 months in order to learn about the epidemiological profile and the risk factors that promote low back pain in the population served.

To this end, interviews were conducted by trained researchers based on questionnaires they prepared with questions aimed at characterizing the epidemiological/clinical profile, in addition to the following instruments:

- ODI - The ODI has ten sections, each section consisting of six alternatives, the first with a value of 0 and the last with a value of 5 . The value obtained can be expressed as a percentage, on a scale of $0 \%$ (no disability) to $100 \%$ (bedridden). The total score is calculated using the following formula: ([the sum of the answers to all questions : (the number of questions answered $\times 5$ )] $\times 100$ ). The values are interpreted as: 0-20\% minimal disability, 21-40\% moderate disability, $41-60 \%$ severe disability, $61-80 \%$ crippled and $81-100 \%$ bedridden. ${ }^{10}$ - RM - The RM is composed of 24 items and the total score is the sum of the items selected by the patients, ranging from zero (no disability) to 24 (severe disability). Values greater than 14 points indicate moderate physical disability. The minimum clinically significant difference is 5 points. ${ }^{11}$

- VAS for pain - The VAS for pain is a line ten centimeters in length with indications ranging from the absence of pain to the worst pain experienced (incapacitating pain) and the subject marks the point on the line that represents the intensity of their pain. ${ }^{12}$

The sample calculation was based on the point prevalence of low back pain in the young adult population (above 18 years of age) of $23 \%$ in a contingent of 11 million inhabitants and on the data about the estimated population of the East Zone of São Paulo. In addition, considering the number of 13,408 hospitalizations in the HSM-Itaquera from January to June $2018,{ }^{13}$ an attempt was made to estimate a sample within a confidence interval of $95 \%$ and a margin of error of $10 \%$. The result was a minimum size of 62 participants using the sample calculator at https://comentto.com/calculadora-amostral/ 
The results obtained for the questionnaires used in the patient interviews were tabulated in a spreadsheet and analyzed using the IBM SPSS ${ }^{\circledR}$ (version 20.0) statistical program. Descriptive and inferential statistical analysis of the data obtained were performed, considering values of $\mathrm{p}<0.05$ statistically significant.

\section{RESULTS}

Ninety patients were interviewed on two different floors of the HSM-Itaquera, which have a total of 146 beds, from December 2018 to February 2019. The specific reasons for hospitalization were unknown, but the patients were distributed among orthopedics, vascular surgery, general surgery and neurology specialties, with the proportions intentionally undefined.

The patients were located in wards on the second and fourth floors of the hospital. About $55.56 \%$ of them self-identified as women (female) and $44.44 \%$ self-identified as men (male) with a total sample standard deviation (SSD) of $29.40 \%$.

Regarding distribution by age range, the largest group fell between 56 and 60 years of age (15.56\%), followed by the 41 to 45 years of age group (13.33\%) and the 36 to 40 years of age group $(12.22 \%)$, with the mean age coinciding with the 46 to 50 years of age group (4.15\%).

In relation to body mass index (BMI), calculated as weight divided by height squared, $47.78 \%$ of the interviewees (SSD 12.52\%) were in the eutrophic range, which according to the Ministry of $\mathrm{He}$ alth is defined as a BMI value between 18.5 and $24.9 \mathrm{~kg} / \mathrm{m}^{2} .{ }^{14}$

Regarding education level, most patients (around 30\%, SSD $10.01 \%)$ had completed high school, with the mean education level achieved corresponding to high school incomplete.

The per capita family income of most of the sample $(45.56 \%$, SSD $14.51 \%$ ) was in the range of 1 to 2 minimum salaries. Most of the interviewees (56.56\%, SSD $20.74 \%$ ) reported being actively employed, whether formally or informally. When asked whether or not they had health insurance, around 90\% said they did not.

In addition, behavior and comorbidity data were collected. Regarding tobacco use and alcohol consumption, a large portion of the interviewees said they had never smoked (52.22\%, SSD 16.37\%) or consumed alcohol (57.78\%, SSD 11.00\%). Questions about the practice of leisure physical activity were also asked, with individuals who practice $30 \mathrm{~min} /$ day or at least $150 \mathrm{~min} /$ week considered active, but the greatest number of responses were classified as inactive (46.67\%, SSD 16.02\%), that is, complete absence of physical activity during leisure. The practice of domestic activities was also verified with an active frequency of $70.00 \%$ (SSD 32.57\%). Regarding the practice of physical activity at work, around 55.22\% (SSD 27.15\%) said they were active. Consequently, around $40.00 \%$ (SSD 18.69\%) said they were physically active in their commute to and from work.

Other data observed were hours of sleep and hours watching television. The mean hours watching television was 4 hours or more per day and around 50\% (SSD 23.33\%) of the participants said they slept between 7 and 8 hours per day, with the mean value in the same subgroup. It was observed that less than 6 hours or more than 9 hours of sleep per day had an influence on a higher level of pain in the patients interviewed.

In order to determine the prevalence of low back pain among the patients interviewed, they were asked to classify their current back pain using the VAS for pain. The results obtained yielded a mean of $5.79 \mathrm{~cm}$, but the most frequent score was 3, indicated by 49 interviewees (54.44\%, SSD 15.01\%).

Bearing in mind that 13 individuals reported feeling no pain, that is, they gave a score of 0 on the VAS, in the calculation of prevalence 77 out of the total possible population reported some degree of back pain. The estimated prevalence would be $52.73 \%$ for the total population.

The ODI and RM questionnaires were also used as instruments and the results are reported in Tables 1 and 2 . Here, according to the ODI scores, a higher frequency (66.67\%, SSD $26.42 \%$ ) of patients was found to be in the minimal disability range, with the mean falling
Table 1. Distribution of the possible ODI* questionnaire results.

\begin{tabular}{c|c|c|c|c}
\hline Classification & Interval & Frequency & Percentage (\%) & SSD** \\
\hline Minimal disability & 0 to $20 \%$ & 60 & 66.67 & \\
\hline Moderate disability & 21 to $40 \%$ & 11 & 12.22 & \\
\hline Intense disability & 41 to $60 \%$ & 11 & 12.22 & \\
\hline Crippled & 61 to $80 \%$ & 6 & 6.67 & \\
\hline Bedridden & 81 to $100 \%$ & 2 & 2.22 & \\
\hline Total & & 90 & 100 & 26.42 \\
\hline
\end{tabular}

Source: Prepared by the author, ${ }^{\star} \mathrm{ODI}$ - Oswestry disability index, ${ }^{* \star} \mathrm{SSD}$ - sample standard deviation.

Table 2. Distribution of the possible $\mathrm{RM}^{\star}$ questionnaire results.

\begin{tabular}{|c|c|c|c|c|}
\hline Classification & Interval & Frequency & Percentage (\%) & SSD** \\
\hline No disability & 0 & 16 & 17.78 & \\
\hline Mild disability & $\geq 5$ and 14 & 40 & 44.40 & \\
\hline Moderate disability & $\geq 14$ & 32 & 35.56 & \\
\hline Severe disability & 24 & 2 & $2 / .22$ & \\
\hline Total & & 90 & 100 & 18.80 \\
\hline
\end{tabular}

into the moderate disability range. The RM scores showed a higher frequency of patients (44.40\%) in the mild disability range.

In the evaluation of the relationship between the variables sex, physical activity at work, occupation, hours of sleep, working hours and the ODI and RM instruments, no statistical significance was found, as both the Student's t-test and ANOVA yielded a value of $p<0.05$.

In the relationship between VAS and the age range, the highest peak of pain was recorded in the 46 to 50 years of age group, with a mean of 8.3 (SSD 3.14). Finally, the relationship between the ODI and RM tools was evaluated in a more qualitative way and later quantitatively using the ANOVA test for this purpose. It is worth mentioning the compatibility between both questionnaires for some groups. For example, the minimal disability and no disability subgroups reached $100 \%$ and $85 \%$ for mild disability, that is, all individuals who had a score of no disability in the RM had minimal disability in the ODI. It is noted that this relationship diminishes as the scores worsen returning to the $50 \%$ combination between intense disability (ODI) and severe disability (RM).

\section{DISCUSSION}

The main factor favorable to this study is that it can be considered a pioneering assessment conducted in the East Zone of the city of São Paulo allowing the compression of possible risk factors and better management of patients through prior knowledge of their clinical/epidemiological profile. ${ }^{15}$

It is difficult to find systematic studies conducted in Brazil that discuss the prevalence rates of low back pain in the population and among its subgroups. The great heterogeneity of the studies prevents summarizing the rates of prevalence over time. In general, the annual prevalence of low back pain is about $50 \%$ in adults and between $13.1 \%$ and $19.5 \%$ in adolescents. ${ }^{1}$

In a study covering the southeast metropolitan region of the city of São Paulo with a sample of 300 individuals of both sexes, over 18 years of age, encompassing the Aricanduva complex, which may be close to the profile observed in this study given the approximate location, the results showed a 10\% point prevalence rate of low back pain, a 43.3\% prevalence rate of low back pain throughout the year and $58.3 \%$ rate of experiencing low back pain at some point in life. ${ }^{16}$ The point prevalence observed in the present study was higher, at around $52.7 \%$. However, it is noteworthy that there are few studies of low back pain prevalence focused on institutionalized individuals.

Another study conducted in the region of Campinas, in the state of São Paulo, with about 1,118 non-institutionalized individuals of both 
sexes, between 18 and 59 years of age, reported a point prevalence of $30.6 \%$ with little distinction between the sexes, $26.5 \%$ for the women and $22.4 \%$ for the men. ${ }^{15}$ In the present study the point prevalence rate obtained was $30.13 \%$ for the women and $22.60 \%$ for the men.

A meta-analysis of the prevalence of low back pain in the elderly (above 60 years of age) showed about $55.55 \%$ of women have some degree of low back pain and about $80 \%$ of men report back pain. ${ }^{16}$

Some studies point to sociodemographic (age, sex, household income and education level), health status, lifestyle or behavior (tobacco use and sedentarism) and occupational (strenuous physical work and repetitive movements) factors as risks for the development of low back pain. ${ }^{1}$ In a midsize city in Brazil, a study was conducted that explored the link between low back pain and the factors mentioned above and the results suggested an association of pain with the female sex, older age, less education, altered sleep and excess weight. The adjusted model showed that overweight people between 45 and 60 years of age with some kind of sleep issue seemed to be a group at risk for low back pain. ${ }^{2}$

In a study of 67 women in the first to third trimesters of their pregnancies, the prevalence of low back pain was $77.6 \%$. The sample consisted of young pregnant women (23 years of age), of color (37.3\%), married $(74.6 \%)$, housewives (58.2\%) and who had completed their basic education (50.7\%). Only gestational age proved to be a risk factor for developing low back pain during pregnancy. ${ }^{17}$

In a study conducted in 2016 at the University of Florence, in Italy, around 210 post-menopausal women between 50 and 69 years of age were divided into one group that performed physical activity and one group that did not and were monitored for 24 months. The prevalence of low back pain in the group that performed physical activity was $33.3 \%$ at the beginning of the study and $21.6 \%$ in the follow-up $(p=0.02)$, while, in the group of women who did not receive the intervention, the prevalence of low back pain was $32.4 \%$ at the beginning and $25.9 \%$ in follow-up ( $p=0.30$ ). This study pointed to menopause itself as a possible risk factor for the development of low back pain. No less important, the study highlights the positive action of physical activity in reducing the prevalence rate in women. ${ }^{18}$

Systemic review studies conducted in developed countries, where the physical demands at work are less intense, show that the prevalence of low back pain is twice as high as that of low-income countries, where the physical demands of work are greater, supporting the hypothesis that the practice of physical activity even outside of leisure can be a protective factor against low back pain. ${ }^{1}$

Another risk factor of the study was hours of sleep, which may or may not be linked to sleep disorders. Thus, a data element that is possibly relevant was the comparison between hours of sleep and the mean VAS score. Using the Tukey test, a statistical significance of $p=0.007$ was found, mainly in the subgroup of people who sleep less than 6 hours compared to the others, with a significance of $p=0.005$ compared to the 7 -to-8-hour range. ${ }^{16}$

However, there is a group of factors not addressed in this study, which is gaining more and more visibility in its association with low back pain - psychosocial factors, especially the influence of the emotional aspects. In a study conducted in China by Shizheng et al. published at the beginning of 2019, a possible relationship between chronic low back pain and emotional influence was confirmed, since psychological and emotional factors play an important role in the perception of pain. ${ }^{19,20}$

Some comparisons have been made between the ODI, RM and VAS instruments and other variables (demographic, behavioral and occupational) in this study. Thus, it is necessary to discuss the relationships established and reflect on the effectiveness of these tools.

There are some relevant relationships in relation to the frequencies versus the results obtained in the ODI, but they did not achieve statistical relevance ( $p>0.05)$. For example, when compared to occupation, the highest frequency is found in the correlation between minimal disability and active subjects, around $40.00 \%$ with $p=0.607$, between the two variables. This corroborates and is in line with what was previously mentioned about work relationships in developed countries. ${ }^{1}$ Likewise, the association of ODI with hours of sleep. In this regard, the highest score obtained in the test results was linked to the individuals who slept less than 6 hours tied to bed-ridden individuals (with a frequency of $2.22 \%$ and $p=0.158$ ). The greatest sensation of pain seems to be a degree of impairment caused in patients by an inadequate period of sleep.

This study showed a strong correlation between the RM and the VAS $(r=0.73)$ and a moderate correlation with Schober's test and the degree of anterior spinal flexion $(r=-0.52$ and $r=0.42$, respectively). ${ }^{8}$ However, there were no important outcomes from its use in this study. When the relationship between the variables and the RM questionnaire were compared, no statistical significance was achieved. The indices were similar to the ODI questionnaire. The association with occupation also revealed a higher frequency with the minimum questionnaire score (mild disability) tied to the active individuals with $p=0.217$. Consequently, when verifying the combination with the variable hours of sleep, there was also coincidence between the grade on the scale, that is, "severe disability", and the smaller number of hours of sleep, but with a value of $p=0.671$

In this study, statistical significance was observed in the relationship between the VAS and the ODI $(p=0.000)$. This result corroborates the statement that the VAS becomes more efficient when administered together with other pain assessment instruments.

This study has several limitations imposed both by the location where it was conducted, as it is a hospital environment with care provided by different teams and has different equipment distributed among the rooms, with different beds for example, which could influence the onset of back pain, and by the instruments administered for the assessment. Although the questionnaire prepared by the researchers consisted of combinations of questions based on studies conducted in cities with characteristics similar to those of São Paulo, there still need to be better adaptation and validation for the population profile served. ${ }^{15}$

Thus, the validated questionnaires that measure the disability level caused by low back pain also have their limitations, especially when it comes to addressing the sexual life of the interviewees, as well as the objectivity of the parameters evaluated to approximate the signs and symptoms referred to by the patients.

\section{CONCLUSION}

This study allows us to conclude that there is a higher prevalence of low back pain among institutionalized individuals, especially those hospitalized, compared to the rates observed outside of the context of hospitalization. There are risk factors that contribute significantly to the development of low back pain, such as occupation, sedentarism, sleep quality, as well as psychosocial factors.

Thus, more studies need to be conducted in this context, since it is difficult to find systematic studies conducted in Brazil that discuss the prevalence rates of low back pain in the population and in its subgroups, especially in the case of hospitalized individuals.

All authors declare no potential conflict of interest related to this article.

CONTRIBUTION OF THE AUTHORS: Each author made significant individual contributions to this manuscript. JPSN and LCLR: substantial contribution to the concept or design of the work and data interpretation, discussion of the results, writing and critical review of its intellectual content. JPSN, FAMN, RYN and MMS: substantial contribution to the acquisition of the data, discussion of the results and critical review of the intellectual content. JPSN, FAMN RYN, MMS and LCLR: review and approval of the final version of the manuscript. 


\section{REFERENCES}

1. Nascimento PR, Costa LO. Low back pain prevalence in Brazil: a systematic review. Cad Saúde Pública. 2015;31(6):1141-55. doi: 10.1590/0102-311X00046114.

2. Zanuto EAC, Codogno JS, Christófaro DGD, Vanderlei LCM, Cardoso JR, Jefferson $R$, et al. Prevalência de dor lombar e fatores associados entre adultos de cidade média brasileira. Ciênc Saúde Coletiva. 2015;20(5):1575-82. doi: 10.1590/141381232015205.02162014.

3. Abreu ATJB, Ribeiro CAB. Prevalência de lombalgia em trabalhadores submetidos ao programa de reabilitação profissional do Instituto Nacional do Seguro Social (INSS), São Luis, MA. Acta Fisiatrica. 2010;17(4):148-52.

4. Brasil. Protocolo clínico e diretrizes terapêutica dor crônica. Portaria SAS-MS n. 1.083, de 02 de outubro de 2012. [Acesso em: 12/03/2020]. Disponível em: https://portalarquivos2. saude.gov.br/images/pdf/2014/dezembro/15/Dor-Cr--nica.pdf.

5. Menezes A. Pesquisa Nacional de Saúde - PNS. 2013 [Acesso em: 12/03/2020]. Disponível em: https://biblioteca.ibge.gov.br/visualizacao/livros/liv94074.pdf,

6. Silva MC da, Fassa SCG, Valle NCJ. Dor lombar crônica em uma população adulta do Sul do Brasil: prevalência e fatores associados. Cad Saúde Pública. 2004;20(2):377-85. doi: 10.1590/S0102-311X2004000200005

7. Brazil AV, Ximenes AC, Radu AS, Fernades AR, Appel C, Maçaneiro CH, et al. Diagnóstico e tratamento das lombalgias e lombociatalgias. Rev Bras Reumatol. 2004;44(6):419-25. doi: 10.1590/S0482-50042004000600005.

8. Lorenc T, Palczewski P, Wójcik D, Glinkowski W, Gołębiowski M. Diagnostic Benefits of Axial-Loaded MRI Over Recumbent MRI in Obese LBP Patients. Spine (Phila Pa 1976). 2018;43(16):1146-53. doi: 10.1097/BRS.0000000000002532.

9. Nice UK. Low back pain and sciatica in over 16s: assessment management - NICE guideline 2016 [Acesso em: 18 maio 2017]. Disponível em: https://www.nice.org.uk/guidance/ng59.

10. Vigatto R, Alexandre NM, Correa Filho HR. Development of a Brazilian Portuguese version of the Oswestry Disability Index: cross-cultural adaptation, reliability, and validity. Spine (Phila Pa 1976). 2007:32(4):481-6. doi: 10.1097/01.brs.0000255075.11496.47.

11. Nusbaum L, Natour J, Ferraz MB, Goldenberg J. Translation, adaptation and validation of the
Roland-Morris questionnaire - Brazil Roland-Morris. Braz J Med Biol Res. 2001;34(2):20310. doi: 10.1590/S0100-879X2001000200007.

12. Ciconelli RM, Ferraz MB, Santos W, Meinão I, Quaresma MR. Tradução para a língua portuguesa e validação do questionário genérico de avaliação de qualidade de vida SF-36 (Brasil SF-36). Rev Bras Reumatol. 1999;39(3):143-50.

13. Hospital Santa Marcelina. To Title - Estatísticas - Nossos números, Available at 2019 [Acesso em: 12/03/2020]. Disponível em: https://santamarcelina.org/hospital/ nossos-numeros/.

14. Brasil - Ministério da Saúde. Cadernos de Atenção Básica - Estratégias para o cuidado da pessoa com doença crônica. Brasília: Ministério da Saúde, 2014 [Acesso em:12/03/2020]. Disponível em: http://bvsms.saude.gov.br/bvs/publicacoes/estrategias_cuidado_pessoa_doenca cronica cab35.pdf

15. Iguti AM, Bastos TF, Barros MB de A. Dor nas costas em população adulta: estudo de base populacional em Campinas, São Paulo, Brasil. Cad Saúde Pública. 2015;31(12):2546-58. doi: 10.1590/0102-311X00178114

16. Brasil - Ministério da saúde. Legislação do SUS [Acesso em:12/03/2020], 2015. Disponível em http://bvsms.saude.gov.br/bvs/publicacoes/progestores/leg_sus.pdf.

17. Assis RG, Tibúrcio RES. Prevalência e características da lombalgia na gestação: um estudo entre gestantes assistidas no programa de pré-natal da maternidade dona Íris em Goiânia. Trabalho de conclusão de curso [Trabalho de conclusão de curso]. Goiânia: Universidade Católica de Goiás, 2004

18. Marini M, Bendinelli B, Assedi M, Occhini D, Castaldo M, Fabiano J, et al. Low back pain in healthy postmenopausal women and the effect of physical activity: A secondary analysis in a randomized trial. PLoS One. 2017;12(5):e0177370. doi: 10.1371/ journal.pone.0177370.

19. Crofford LJ. Psychological aspects of chronic musculoskeletal pain. Best Pract Res Clin Rheumatol. 2015;29(1):147-55. doi: 10.1016/j.berh.2015.04.027.

20. Du S, Hu Y, Bai Y, Hu L, Dong J, Jin S, et al. Emotional distress correlates among patients with chronic nonspecific low back pain: a hierarchical linear regression analysis. Pain Pract. 2019;19(5):510-21. doi: 10.1111/papr.12772. 